Finanse, Rynki Finansowe, Ubezpieczenia nr 1/2018 (91)

DOI: $10.18276 /$ frfu.2018.91-18

s. $219-229$

\title{
Directions of change in corporate fringe benefits
}

\author{
Maria Sierpińska, Beata Kulisa*
}

\begin{abstract}
Purpose - The purpose of the paper is to show the directions of changes in the area of the most popular and most desirable benefits. The types and functions of non-wage benefits are presented, granted to employees by enterprises in order to increase motivation and involvement in the performance of their tasks. Companies make use of a vast range of non-wage benefits of different impact.

Research methodology - The paper uses a critical analysis of the reference materials and analysis of empirical data obtained as a result of surveys conducted each year by Sedlak \& Sedlak.

Results - The analysis of survey data showed that the most popular benefits are: primary and special health care, professional training and courses, gym and fitness club passes, use of business phones for private purposes and life insurance. While the most desirable additional benefits among employees include an extended medical package, a company car for private use and flexible working hours.

Originality/value - Recognising the most popular and most desirable benefits makes it easier for enterprises to select them, particularly since the employees' preferences change over time. This is extremely important for companies because benefits allow them to improve employees' commitment and increase their motivation to work. The Y generation is entering the labour market and employers must consider their expectations when designing benefit packages.
\end{abstract}

Keywords: benefit types, employee commitment, the most popular benefits, the most desirable benefits

\section{Introduction}

In addition to basic salaries and bonuses, in many enterprises employees receive non-wage benefits, also known as fringe benefits. These are all kinds of additional benefits which are financial or in-kind supplements to salaries and bonuses. Benefits are a financial or organisational cost for the employer and at the same time a gain for the employee. Benefits do not constitute remuneration given in exchange for the quantity and quality of labour provided, but arise in connection with affiliation to an organisation (Woźniak, 2012, p. 119). Benefits in other countries are understood differently than in Poland, e.g. in USA, anything that is not a net salary is a benefit, whereas in Poland for a supplement to be considered a benefit, it must be added to gross pay. Accordingly, disability or sickness insurance in the USA is treated as a benefit required by law, whereas in Poland such insurance is only one of the components of gross pay. The same applies to retirement and holiday entitlements. In Poland, they are statutory and are not treated as benefits. The relatively high percentage share

\footnotetext{
* prof. dr hab. Maria Sierpińska, Wyższa Szkoła Finansów i Zarządzania w Warszawie, Katedra Finansów, e-mail: msierpinska@o2.pl; dr Beata Kulisa, Uniwersytet Ekonomiczny w Krakowie, Katedra Ekonomiki i Organizacji Przedsiębiorstw, e- mail: bkulisa@interia.pl.
} 
of the value of benefits in the total remuneration structure in Anglo-Saxon countries compared to Poland is largely the result of a different approach to the way they are calculated and not the result of actual differences (Sedlak, 2014, p. 10).

The paper aims to show directions of change in the area of the most popular benefits given by enterprises and additional perks and benefits which employees want the most.

\section{Types of benefits}

In the last few years, the most popular benefits included basic medical care, gym and fitness club passes, training and vocational courses. However, increasingly over the years, interest has been growing in other forms of benefits, especially specialist medical care, possibility of having a company car for personal use, a computer or a company phone for private purposes. Employees have become increasingly interested in life insurance or flexible working time. Therefore, the introduction of a cafeteria system in a company, i.e. a system where each employee decides what to include in his/her benefits package appears to be a very good solution. Usually, an employer determines the list of available benefits and the amount that it may spend on them (Tapa, 2013). Meanwhile, the Y generation is entering the labour market - it now accounts for $50 \%$ of the total labour force. Employers must consider this while designing a benefits package for both this and the older generations. In order to increase the appeal of benefits in the eyes of employees, companies should focus not only on the content of the additional benefits package, but also on their value.

Authors of pertinent literature, enumerate a number of benefits. The most important are:

- Medical services. With regard to this supplement, the employer covers the cost of services for an employee at a selected clinic (Borkowska 2012, p. 474). The package may also cover employees' family. The medical package may also include vaccinations, consultations, home visits, coverage of hospital costs, visits to the dentist, ophthalmologist, rehabilitation costs, specialist check-ups, stays in a sanatorium, as well as reimbursement of the costs of visits to many other specialists. Larger companies may also employ their own doctor, or offer general medical care to employees along with specialist check-ups covering the entire cost or a part thereof. The advantage of this type of benefit is in the increased sense of security for employees and their families (Lenik, 2012, pp. 114-115).

- Employee accommodation - it is available when the place of an employee's permanent or temporary residence is far from the workplace. In this case, the employer covers the entire or partial costs of renting an apartment for an employee. An employee may also be entitled to a family separation allowance in such circumstances.

- Additional pension and insurance schemes - these include insurance for the elderly, but also for events and accidents occurring both at work and outside. These types of insurance schemes usually cover employees, but sometimes also extend to family members. They also feature life insurance policies (Borkowska 2012, p. 475). 
- Housing allowance - it consists in the purchase of a house or flat, payment of rent or partial participation in costs. It also includes the payment of renovation costs, and may include a related loan. Housing allowances may also involve a flat entitlement, whereby an employee can use a flat during the period of employment in a given company. Sporadically an employee not only receives a flat or house for his use, but the company also employs a housekeeper, gardener, etc. (Borkowska, 2012, p. 475).

- Developmental and educational allowance - it improves an employee's professional qualifications through studies, courses, seminars, conferences and other forms of employee education. The employer covers the costs of an employee's improvement, either in part or in full.

- Cultural, recreational and sports perks and benefits - they are granted to employees and their families, especially their children in the form of gym, swimming pool or other sport and recreational activities passes. They can also involve partial financing of trips for the employee and his family or tickets for cultural events (Borkowska 2012, p. 475).

- Flexible working time - it involves shorter working hours or flexible starting or ending of working hours. The benefit also includes flexible organisation of the work, which is in many cases is highly convenient, especially when it concerns employees with children and various family responsibilities (Borkowska, 2012, p. 475).

- Childcare benefits - they consist in providing a place for a child in a nursery or a kindergarten, but also organisation of summer or winter camps during holidays.

- Transport services are connected with providing a company car, with or without a chauffeur, but also the right to use a company car for private purposes. This benefit may also come in the form of free urban transport tickets, free or partially free parking space etc.

- Meal allowance - this can involve a meal in an employee canteen. However, the scheme often features meal vouchers allowing an employee and his family to purchase a meal or food products (Lenik, 2012, p. 116).

- Financial benefits mainly involve a loan at an interest rate which is more favourable than that granted by banks. The loan may be granted for various purposes, most often to purchase a flat, a car, to renovate property, purchase a plot of land, etc. (Majewska, 2014, p. 133).

- An allowance in recognition of special skills - it targets employees with high professional qualifications, holders of academic titles, post-graduates, as well as employees boasting diplomas certifying completion of highly valued specialist courses (Twardo, 2010, p. 50).

- Corporate retreat-related perks - they help to build closer relations among employees and to befriend people. Inclusion occurs during corporate retreats or training meetings, where employees have the opportunity of closer contact with colleagues, which in 
turn improves the atmosphere and work efficiency and leads to involvement at a group level.

- Commuting expenses are usually the responsibility of the employee, and the employer is not obliged to cover the costs related to getting to and from work. However, employers increasingly gran their employees various allowances in the form of bus or train tickets, reimburse fuel costs or arrange group travel, and even if they do not cover the costs completely, may apply a partial reimbursement of commuting costs (Majewska, 2014, p. 97).

\section{Benefits versus motivation and employee involvement}

Benefits play an important role in motivating employees and encouraging them to work effectively. Motivation is the driving force of human behaviour and actions. Employers wishing to succeed must implement an array of various instruments that will stimulate their employees' work. These instruments must include not only incentives motivating the employee to get more involved in the work, but also appropriate working conditions that will guarantee the employee's personal satisfaction. In order to achieve the intended outcomes, companies widely use non-wage benefits. In some companies employees are given a choice between a low pay rise and, as an alternative, a certain benefit. In order for the salary supplement to fulfil a motivational role, it is important to reliably and consistently evaluate the effects of an employee's work, and then, taking the assessment into account, determine the size and type of benefit for the employee (Twardo, 2010, p. 80)

S. Borkowska (2012, pp. 468-469) emphasises that benefits not only motivate employees to perform their duties, but also:

- strengthen the effectiveness of the functions of financial wages and supplement them as a result of a better matching of benefits to the individual needs and employee expectations; they also make it possible to increase the competitiveness of the net remuneration package,

- support employee development and education,

- counteract the effects of work-life imbalance or alleviate it, thereby reducing stress,

- positively improve employees' quality of work and non-business life and increase job satisfaction,

- favour employees connection to the company and strengthen their loyalty,

- enhance the individualisation of labour relations, thereby enhancing the flexibility of employees and company, which is desirable in the competitive environment,

- as a consequence, they also contribute to an increase in work productivity.

S. Borkowska also emphasises that salary supplements in the form of fringe benefits are to entice candidates to seek work in the company, as well as to help to keep them in the company and to encourage them to be integrated with the team and to constantly improve their work results and strive to develop themselves and the company. In order for motivation 
through benefits to produce the intended outcomes, it is not only necessary to pay attention to the amount of the benefit, but also to ensure that it is tailored to the individual's expectations and needs. When the type of benefit is suitably tailored to employees' different needs and expectations, then it effectively fulfils the motivational function and brings beneficial effects for the employee and the employer alike (Borkowska, 2012, p. 470).

Benefits are intended to strengthen employees' commitment. It is perceived as a kind of attitude and behaviour on the part of the employee in relation to the goals and tasks being accomplished. It is important that the employee is able and willing to expend an effort for the organisation. It requires creating an emotional connection with his/her work. It also means that he/she accepts the organisation's system of values, culture and working conditions because he/she agrees to fulfil his/her assigned duties with passion and dedication, often voluntarily doing more than is just required of him/her. Involvement is a kind of behaviour characteristic of proactive and conscientious employees, well disposed to their work, capable of flexible adaptation to changing conditions, newly emerging requirements that may be challenging for them (Łukasiński, 2014). A committed person is inclined to act with energy, to devote free time to implement innovations and initiatives aimed at ensuring the improvement of an organisation's functioning and its development. This attitude makes him/her identify with the organisation and its objectives (Macey, Schneider, 2008; Łukasiński 2014). He/she can engage physically and emotionally. Employees' involvement becomes one of the key elements determining the success of the organisation since it can significantly affect their readiness to stay in the organisation, their productivity and loyalty (Mani, 2011; Michalak, 2014, p. 262).

Companies, especially multinationals, caring for their employees often make a real effort of boosting employee involvement. They view it as a foundation for other positive employee attitudes - creativity, efficiency, productivity and innovation. The long-term development of an organisation presupposes creative thinking in order to rationally use resources and implement new products. The employee is expected to take responsibility for the outcomes. He/she should, therefore, participate in activities undertaken by the company, be emotionally connected to the workplace and express a willingness to actively participate in the activities and development of the business entity.

Thus achievement of effective employee involvement requires finding the right motivators. Undoubtedly, they include wage increases, promotions, awards, development opportunities. Such benefits as discounts for the purchase of the company's products, medical care, a mobile phone, a company car or a laptop for private use all play a significant role in stimulating employees' involvement. In addition to remuneration and benefits, employees' involvement is also influenced by cultural factors such as: ethics, brand, reputation, mission and the company's objectives as well as factors related to the workplace, especially the opportunity to use one's creativity, work one likes to do, superiors' attitudes (equity, inspiration, opportunities of personal development) and relationships with colleagues. Juchnowicz (2010, p. 37) also enumerates the possibilities of autonomous action, clear criteria of 
employee appraisal and clear rules of promotion. These affect work satisfaction. A person satisfied with his/her work has a positive attitude towards it, hence he/she may be willing to do more and do it more effectively. Research shows the important role of employees' involvement in their work for the profits of the entire organisation, such as an increase in share price, higher sales achieved by employees, or a higher profit per customer (Michalak, 2014, p. 262).

Benefits packages have many advantages, but it is also possible to identify disadvantages. Typical advantages are, above all, increased employee motivation and involvement. The employee is well aware that in order to receive a benefit again, he/she must repeat the previous achievements, which promotes his/her work efficiency and its maintains it in the long-term. The biggest disadvantage of this approach though is that many, particularly low-level, employees tend to strive for a rise in their basic pay, even by small amounts, and are reluctant to sacrifice their energy to make an effort to secure otherwise unpredictable benefits (Juchnowicz, 2010, p. 25).

\section{Directions of change in corporate fringe benefits}

Historically, fringe benefits have been a form of pay for night shifts or overtime work, extensive experience or function, or involved long service bonuses, allowances for working in difficult conditions, and various in-kind benefits (clothing, coal, etc.) arising out of collective labour agreements. Some of these add-ons are mandated by the labour law. The widespread belief that the motivational value of such benefits is negligible, coupled with the conviction that they are a significant burden to the company result in the wide-scale abandonment by companies of mandatory fringe benefits (Woźniak, 2012, p. 119). P. Lenik (2012, pp. 8-11) notes that confidence in the effectiveness of wage-based motivation alone in still strongly alive in the mentality of some employees. In the management of modern Polish organisations such motivation is considered to be standard, whereas non-wage motivators are treated as secondary or even marginal.

In order to determine the directions of change in benefits packages, the authors use the results of tests conducted annually by the company Sedlak \& Sedlak. These extensive surveys have typically sampled 1,500-3,000 employees. In 2015, the study sampled 2,709 employees, in 2016 - 1,577 employees, and in 2017 - 2,962 employees. Similar research has also been conducted by scientists (Garstka, 2015; Różańska-Bińczyk, 2014), but its scope has not been so broad.

The size of the company, the industry in which it operates and the origin of the company's owner have a major impact on the popularity of non-wage employee benefits (Table 1).

In 2017, the popularity of benefits declined relative to 2014. In 2014, more than $50 \%$ of micro-enterprises and $85 \%$ of small enterprises used non-wage benefits. In the last year of the study period, only $27 \%$ of micro-enterprises and $57 \%$ of small enterprises used them. 
A similar trend was observed in medium, large and very large companies. However, a comparison of the rate of the use of non-wage benefits indicates that these benefits are much more prevalent in large enterprises than in small ones. It should also be added that non-wage benefits are given to employees much more widely by companies with a majority foreign shareholding than by those with predominantly Polish ownership. In 2017, benefits were given by $91 \%$ of companies with a majority foreign ownership compared to just $64 \%$ of companies with a majority Polish shareholding.

\section{Table 1}

Popularity of benefits in Polish enterprises in 2012-2014 by size of the organisation

\begin{tabular}{lllllll}
\hline Description & 2012 & 2013 & 2014 & 2015 & 2016 & 2017 \\
\hline Micro (1-9 employees) & $\cdot$ &. & 53.2 & 31.0 & 23.0 & 27.0 \\
Small (10-49 employees) & 70.0 & 51.0 & 85.0 & 52.0 & 59.0 & 57.0 \\
Medium (50-249 employees) & 85.0 & 73.2 & 94.0 & 69.0 & 73.0 & 77.0 \\
Large (250-499 employees) & 83.0 & 80.8 & 100.0 & 81.0 & 82.0 & 81.0 \\
Very large (over 500 employees) & 95.0 & 88.7 & 100.0 & 87.0 & 90.0 & 90.0 \\
\hline
\end{tabular}

Source: authors' own calculations based on: Podsumowanie raportu , Świadczenia dodatkowe w oczach pracowników za lata 2012-2017' Sedlak \& Sedlak.

Equally interesting are the results of research into the share of benefits in total remuneration. In 2016, 78\% of employees stated that benefits should account for no more than $10 \%$ of the total remuneration, compared to $82 \%$ in 2017 . In 2017 a mere $4 \%$ would tolerate a more than $20 \%$ share of benefits in the total remuneration, compared to $3 \%$ in 2016. Employees prefer a cash-settled salary (Sedlak \& Sedlak).

The statistics in Table 2 show the direction of change in the most widespread employee benefits in Poland in 2012-2017. In 2012-2015, the most popular non-wage benefit was basic medical care and gym and fitness club passes. Physical fitness and fitness club passes were the most popular forms of non-wage benefits among nearly half of the employees surveyed.

\section{Table 2}

Most popular fringe benefits in 2012-2017

\begin{tabular}{lllllll}
\hline Type of benefit & 2012 & 2013 & 2014 & 2015 & 2016 & 2017 \\
\hline Basic medical care package & 74.0 & 72.5 & 79.0 & 48.0 & 36.3 & 36.1 \\
Gym, fitness club pass & 66.0 & 73.0 & 67.0 & 45.7 & 46.1 & 47.9 \\
Specialist medical care &. &. &. & 45.0 &. &. \\
Company phone for private use &. &. &. & 41.0 & 41.6 & 43.5 \\
Training, vocational courses & 82.0 & 81.0 & 74.0 &. & 36.5 &. \\
Life insurance plan &. &. &. &. &. & 38.9 \\
\hline
\end{tabular}

Source: authors' own calculations based on: Podsumowanie raportu ,'Świadczenia dodatkowe w oczach pracowników za lata 2012-2017”' Sedlak \& Sedlak. 
In 2016-2017, however, basic medical care lost its appeal in favour of specialist care, and employees were interested in an extended medical package comprising both basic and specialist healthcare. In 2015, 45\% of respondents indicated that specialist medical care was popular among employees. The 2017 benefits packages started featuring life insurance. It should also be noted that in 2016-2017 respondents welcomed the use of a business phone for private purposes. By contrast, courses and training lost their appeal. Dedicated in-company training proved to be more effective than external training.

Table 3

Fringe benefits ranked as the most desirable by employees in 2012-2017

\begin{tabular}{lcccccc}
\hline Type of benefit & 2012 & 2013 & 2014 & 2015 & 2016 & 2017 \\
\hline Basic medical care package & 36.0 & 44.0 & 30.0 & & & \\
Specialist medical care & & & & 51.0 & & \\
Extended medical care package & & & & & 50.2 & 46.1 \\
Gym pass & 26.0 & 40.0 & 31.0 & 28.0 & 21.7 & 19.6 \\
Company car for private use & & & & 24.0 & 23.8 & 24.4 \\
Flexible working time & 23.0 & 30.0 & 26.0 & & & 21.9 \\
Courses and training & & & & & \\
\hline
\end{tabular}

Source: authors' own calculations based on: Podsumowanie raportu „Świadczenia dodatkowe w oczach pracowników za lata 2012-2017”'Sedlak \& Sedlak.

The statistics in Table 3 facilitate a comparison between employee expectations and actual benefits offered by companies. Every second employee expected an extended medical package containing basic and specialist medical care. The desirability of gym and fitness club passes decreased, while employee expectations of a company car for private use and flexible working time remained almost unchanged. One in four employees would have liked the use of a company car for private needs, and one in five expected flexible working hours. Flexitime was most appealing to employees of IT companies. Similarly, gym and fitness club passes were desirable in the IT, telecommunications and banking industries due to the nature of work there. Many foreign companies open up business operations in Poland. By offering a significant number of fringe benefits they hope to recruit the best specialists and to ensure their commitment and loyalty. Often, competitive companies would poach staff by offering them additional non-wage benefits.

Benefits are used by companies all around the world. A payroll survey conducted by Nigel Frank International in March 2017 shows that the most popular benefits among employees abroad included: laptop (59.6\%), discretionary bonuses (49.3\%), medical care $(45.3 \%)$ and work from home (41.2\%) or flexible working hours (35.7\%), which means that employee benefits packages all over the world seem to be very similar, as do employee expectations in this regard. However, in order to stand out from the rest, companies around the world use increasingly original types of non-wage benefits. In Australia, after 15 years in one 
organisation, employees can go on a 13-week paid leave, and in France after working for at least 24 months, employees can take a 12-month unpaid leave to start their own business. Should the undertaking fail, after the twelve-month period the employer must reemploy the employee in the company under the same conditions as before. In Japan, it is possible to take a "broken heart" leave so as to recover mentally. In 2014, Facebook - as part of its employee benefits - introduced co-financing for freezing and storing oocytes. The company declared that it would cover all costs related to the above-mentioned treatment not only to its employees, but also to the wives and partners of their employees. It is worth adding that in addition Facebook pays up to 4,000 USD to their employees on the occasion of the birth of a child. Google's unique approach to creating a work environment in which new projects are to be created is also widely known. The American giant provides free meals in its office buildings, as well as children's playrooms, gyms, basketball courts and even a hairdresser, launderette and massage parlour. To increase the efficiency of their employees as well as the comfort of their work, the American corporation S.C. Johnson has introduced a concierge service that will help employees in their daily duties, such as picking up items from the launderette or a car from a garage (Nowak, 2017).

\section{Conclusions}

In summary, it should be emphasised that the main purpose of non-wage benefits is to increase employee motivation and commitment. These benefits are increasingly important in the process of employee recruitment and retention. When new generations of employees enter the labour market, benefits packages are modified, and their appeal indicates the possibility of shaping employees' behaviour, so that while fulfilling specific tasks, they satisfy employees' needs and expectations. Going beyond the standard set of non-wage benefits may positively affect not only the development, motivation and retention of employees in the company but also strengthen the importance and image of the company itself. Companies must not focus solely on the most popular benefits - they must also look for new solutions that best suit their employees' expectations. A well-prepared benefits development plan will allow them to be implemented gradually and effectively, while reducing the costs associated with managing them. Companies can use various types of online platforms to provide nonwage benefits and guarantee greater control over them, while increasing their attractiveness. Polish companies enjoy quite a lot of opportunities to introduce additional, attractive benefits packages along the lines of solutions used in the West.

Planning a non-wage benefits system, companies should prepare an attractive original offer of benefits that will allow them to build long-term relationships with employees. These benefits can be tailored to individual needs, ensuring stable development for both employees and the entire organisation itself. The company must not, however, offer an excessive range of benefits, because such fragmentation will reduce their effectiveness and cause some of them not to be used or used only marginally. 


\section{References}

Borkowska, S. (2012). Skuteczne strategie wynagrodzeń- tworzenie i zastosowanie. Warszawa: Wolters Kluwer.

Garstka, M. (2015). Pozapłacowe materialne czynniki motywowania w grupie zawodowej księgowych. Zeszyty Naukowe Uniwersytetu Szczecińskiego, 873, 53-60.

Jaszcz, Ł. (2016). Podsumowanie raportu „Świadczenia dodatkowe w oczach pracowników 2016 roku”. Sedlak $\&$ Sedlak.

Jurczak, K. (2017). Podsumowanie raportu „, Świadczenia dodatkowe w oczach pracowników 2017 roku”. Sedlak $\&$ Sedlak.

Juchnowicz, M. (2010). Zarządzanie kapitałem ludzkim a poziom zaangażowania pracowników. Warszawa: WSHiP. Kłosowska, J. (2012). Podsumowanie raportu „,Polityka świadczeń dodatkowych w 2012 roku”. Sedlak \& Sedlak.

Litwa, W. (2013). Podsumowanie raportu „Świadczenia dodatkowe w oczach pracowników w 2013 roku”. Sedlak $\&$ Sedlak.

Łukasiński, W. (2014). Zaangażowanie pracownika a jakość funkcjonowania organizacji. Ekonomika i Organizacja Przedsiębiorstw, 9, 34-45.

Majewska, R. (2014). Świadczenia pozapłacowe - skutki podatkowe i składkowe. Warszawa: Wyd. C.H. Beck.

Macey, W.H., Schneider, B. (2008). The meaning of employee engagement. Industrial and Organizational Psychology, 1 (1), 3-30.

Mani, V. (2011). Analysis of employee engagement and its predictors. International Journal of Human Resource Studies, 1 (2), 15-26.

Michalak, M. (2014). Czy zarządzanie zaangażowaniem w pracę wymaga uwzględnienia różnorodności pracowników? Prace Naukowe Uniwersytetu Ekonomicznego we Wrocławiu, 350, 261-271.

Nowak, M. (2017). Benefity pracownicze: opieka medyczna i karta sportowa to dziś za mało. Retreived from: https://www.profinfo.pl/sklep/personelplus,7378.html?_ga=2.63361580.2056096123.1510856620411258297.1499886894\#40152321 (20.11.2017).

Lenik, P. (2012). Motywatory pozapłacowe czyli droga do nowej jakości pracowników. Warszawa: Difin.

Różańska-Bińczyk I. (2014). Rola pozapłacowych sposobów motywowania pracowników we współczesnych organizacjach. Prace Naukowe Uniwersytetu Ekonomicznego we Wrocławiu, 350, 336-347.

Sedlak, K. (2014). Total rewards - przyszłość systemów wynagradzania. Benefit, 3, 9-12.

Tapa, K. (2013). Opinie pracowników o benefitach. Benefit, 9, p. 10-12.

Tapa, K. (2014). Podsumowanie raportu „Świadczenia dodatkowe w oczach pracowników w 2014 roku”. Sedlak \& Sedlak.

Tapa, K. (2015). Podsumowanie raportu „Świadczenia dodatkowe w oczach pracowników w 2015 roku”. Sedlak $\&$ Sedlak.

Twardo, D. (2010). Wynagrodzenia i systemy motywacyjne. Warszawa: INFOR.

Woźniak, J. (2012). Współczesne systemy motywacyjne. Warszawa: Wydawnictwo Naukowe PWN.

\section{KIERUNKI ZMIAN W SYSTEMIE BENEFITÓW W PRZEDSIĘBIORSTWACH}

Streszczenie: $\mathrm{Cel}$ - Celem artykułu jest pokazanie kierunków zmian w obszarze najpopularniejszych i najbardziej pożądanych przez pracowników benefitów. Zaprezentowane zostały rodzaje i funkcje pozapłacowych świadczeń przyznawanych pracownikom przez przedsiębiorstwa w celu zwiększenia motywacji i zaangażowania w realizację powierzonych im zadań. Firmy wykorzystują ogromną gamę świadczeń pozapłacowych o różnej sile ich oddziaływania.

Metodologia badań - W artykule zastosowana została krytyczna analiza literatury przedmiotu oraz analiza danych empirycznych pozyskiwanych w wyniku badań ankietowych przeprowadzanych każdego roku przez spółkę Sedlak \& Sedlak.

Wyniki - Analiza danych ankietowych wykazała, że do najpopularniejszych benefitów należy: podstawowa i specjalistyczna opieka medyczna, szkolenia i kursy zawodowe oraz karnety na siłownię i do klubów fitness, wykorzystanie telefonu służbowego do użytku prywatnego oraz ubezpieczenia na życie. Do najbardziej pożądanych przez pracowników świadczeń dodatkowych należą natomiast rozszerzony pakiet medyczny, samochód służbowy do użytku prywatnego i elastyczny czas pracy. 
Oryginalność/wartość - Rozpoznanie najpopularniejszych i najbardziej pożądanych benefitów ułatwia przedsiębiorstwom ich dobór zwłaszcza, że preferencje pracowników zmieniają się w czasie. Jest to niezmiernie istotne dla firm gdyż benefity pozwalają na poprawę zaangażowania pracowników i zwiększają ich motywację do pracy. Na rynek pracy wkracza pokolenie Y i pracodawcy muszą uwzględniać ich oczekiwania przy konstruowaniu pakietu benefitów.

Słowa kluczowe: rodzaje benefitów, zaangażowanie pracowników, najpopularniejsze benefity, najbardziej pożądane benefity

\section{Citation}

Sierpińska, M., Kulisa, B. (2018). Directions of change in corporate fringe benefits. Finanse, Rynki Finansowe, Ubezpieczenia, 1 (91), 219-229. DOI: 10.18276/frfu.2018.91-18. 